\title{
The Combination of Indigenous Knowledge and Geo-Informatics for Water Harvesting Siting in the Jordanian Badia
}

\author{
Rida Al-Adamat ${ }^{1 *}$, Saad AlAyyash ${ }^{1}$, Hani Al-Amoush ${ }^{1}$, Odeh Al-Meshan², Zahir Rawajfih ${ }^{3}$, \\ Akram Shdeifat ${ }^{1}$, Adnan Al-Harahsheh ${ }^{4}$, Mohammed Al-Farajat ${ }^{1}$ \\ ${ }^{1} \mathrm{Al}$ al-Bayt University, Mafraq, Jordan \\ ${ }^{2}$ Jordan Badia Research Programme, Amman, Jordan \\ ${ }^{3}$ Jordan University for Science and Technology, Irbid, Jordan \\ ${ }^{4}$ Mutah University, Karak, Jordan \\ Email: ${ }^{*}$ ridaali@aabu.edu.jo
}

Received May 8, 2012; revised June 5, 2012; accepted July 1, 2012

\begin{abstract}
Jordan is located in an arid to semi arid region where around $90 \%$ of its land receives an average annual precipitation of less than $100 \mathrm{~mm}$ while only $3 \%$ of the land receives an average annual precipitation of $300 \mathrm{~mm}$ or more. Jordan is characterised as a "water scarce" country because the current per capita share of water is estimated to be of the order of $140 \mathrm{~m}^{3}$ per year which is well below the $1000 \mathrm{~m}^{3}$ threshold. Rainwater harvesting is the accumulating and storing, of rainwater. It has been used to provide drinking water, water for livestock, water for irrigation or to refill aquifers as a groundwater recharge. GIS has been widely used in selecting the best sites for water harvesting schemes. This research aims at selecting optimum sites for water harvesting schemes in the Jordan arid lands (Badia) using indigenous knowledge and geo-informatics. To achieve this aim, a community-based research and desktop investigating is applied. The community-based research focused on consulting with 200 stakeholders form local communities where they provided knowledge on opportunities and constrains form their experience on water management in the arid lands where they live and interact. Also they provided information on potential location for water collecting sites that has been used for ages to provide water to humans and livestock. On the other hand, desktop research is conducted on sitting criteria for water harvesting based on physical and socio-economic characteristics. The physical criteria include rainfall volumes, slope, distance to water courses (wadis), distance form geologic faults and soil texture, where socioeconomic criteria include distance to groundwater wells, distance to urban area, distance to agriculture activities and distance to international brooders. This selecting criterion in combination with indigenous knowledge is used within GIS environment to identify optimum sites for water harvesting. GIS analysis resulted in identifying 118 potential sites. Of those, 30 sites had already recommended by the community consultations.
\end{abstract}

Keywords: GIS; Indigenous Knowledge; Water Harvesting; Arid Lands; Jordan

\section{Introduction}

Jordan is located in an arid to semi arid region where around $90 \%$ of its land receives an average annual precipitation of less than $100 \mathrm{~mm}$ while only $3 \%$ of the land receives an average annual precipitation of $300 \mathrm{~mm}$ or more [1]. Jordan is characterized by severe weather conditions, therefore great temporal and spatial variations in rainfall; runoff and evaporation amounts are expected [1].

Jordan is characterised as a "water scarce" country because the current per capita share of water is estimated to be of the order of $140 \mathrm{~m}^{3}$ per year which is well below

\footnotetext{
*Corresponding author.
}

the international recognized threshold for water scarce countries of $1000 \mathrm{~m}^{3}$ [2-4].

The annual population growth rate in Jordan is estimated to be around $2.8 \%$. Based on this percentage, it is estimated that the total population in Jordan will be around 10 millions by 2020 [5]. This will add more pressures on the existing water resources in the country leading to a massive decrease in per capita to $90 \mathrm{~m}^{3}$ per year by 2025 [6].

Rainwater harvesting is the accumulating and storing, of rainwater [7]. It has been used to provide drinking water, water for livestock, irrigation and ground water aquifers recharge. Various forms of water harvesting have been used traditionally throughout the centuries. 
Some of the very earliest agriculture, in the Middle East, was based on techniques such as diversion of "Wadi" flow (spate flow from normally dry watercourses) onto agricultural fields.

Water harvesting is adapted in arid and semi-arid regions where rainfall is either not sufficient to sustain a good crop and pasture growth or where, due to the erratic nature of precipitation, the risk of crop failure is very high. Water harvesting can significantly increase plant production in drought prone areas by concentrating the rainfall/runoff in parts of the total area [8]. Water harvesting has been practiced in Jordan throughout history for both irrigation and household purposes. There are indications of early water harvesting structures believed to have been constructed over 9000 years ago in Southern Jordan [8]. In the North Eastern of Jordan (Jawa), water was retained by deflection dams 5000 years ago [9].

GIS has been widely used in selecting the best sites for water harvesting schemes (e.g. [6,10-18]). The site selection criteria in most of these references are based on soil and topographic suitability, land cover and land use, and surface runoff generating potential. Hydrologic modeling, remote sensing, and GIS techniques are usually used in the site selection processes of these water harvesting schemes are used in these researches.

The integration between indigenous knowledge and geo-informatics for water harvesting has been explored in various researches (e.g. [19-25]).

There are two major techniques used within GIS environment to select the optimum site for any project; the Weighted Linear Combination (WLC) and the Boolean technique.

The Weighted Linear Combination (WLC) technique is based on standardizing the suitability maps, assigning weights of relative importance to the suitability's maps, combining the weights and standardized suitability maps and obtaining an overall suitability score ([26-31]). While in the Boolean technique, the variables are either true or false. This technique provides site selection of a project based on using either the OR (UNION) or the AND (INTERSECTION) operations ([6,16,32-36]).

The main goal of this project is the development of site selection criteria for rain water harvesting systems in the Jordanian Badia based on the indigenous knowledge and the use of Geo-informatics. In this research, the approach suggested by $([16,23,33])$ will be used for analyzing the data in order to select the optimum sites for water harvesting systems. All criteria will be given equal weights, and 0 and 1 will be used to rate all layers (0: not suitable and 1: suitable). This is in contradiction with ([6,15,35], who used WLC technique because weighting is a very complicated process and might lead to misleading results. According to [35], it is misleading to interpret the weights as general measure of the importance. Incorrect specification of weights is an especially common error in the application of weighted linear combination method (WLC) to spatial problems [35].

\section{Study Area}

The study area is located in the Eastern part of the Jordan, and cover about 55.4 thousands $\mathrm{Km}^{2}$, which comprise about $62 \%$ of the total area of Jordan. Figure 1 shows the location of the study area which extends from north to south eastern parts of Jordan covering areas within Mafraq, Zarqa, Amman, Karak, Ma’an and Aqaba governorates. About 100 thousands inhabitants live in this area Figure 2 shows the population distribution within the study area.

The annual rainfall volumes in the study area vary between $250 \mathrm{~mm}$ in the north western parts to less than $50 \mathrm{~mm}$ in the southern parts. Figure 3 shows spatial distribution of annual rainfall volumes in the study area.

The topography of the study area is gentle in general. The ground surface elevation varies between $500 \mathrm{~m}$ above sea level (m a.s.l) in the middle parts to about $1000 \mathrm{~m}$ a.s.l. in the southern parts and $1200 \mathrm{~m}$ a.s.l. in the northern parts. Figure 4 shows the change in topography of the study area.

The soil textures in the study area comprise of Sandy Loam (South eastern parts of the study area), Loam (Eastern and South Eastern parts of the study area) and small areas with Silty Loam, and Silty Clay Loam textures as shown in Figure 5.

\section{Research Methods}

\subsection{Data Collection}

There are two types of data collected for this research, primary data and secondary data. The primary data include the following:

1) Suggested sites by the local communities for water harvesting in the Badia,

2) Suggested constraints by the local communities for selecting an optimum site for water harvesting which include:

- Distance to International Borders (the allowed distance from borders for livestock owners in the Badia region to graze their livestock),

- Distance to Roads,

- Distance to Urban centers,

- Distance to Agricultural activities,

- Distance to Groundwater wells.

As part of the primary data collection which were mainly from local community, three community consultations were organized with local community members. The participants in these consultations cover livestock owners, 


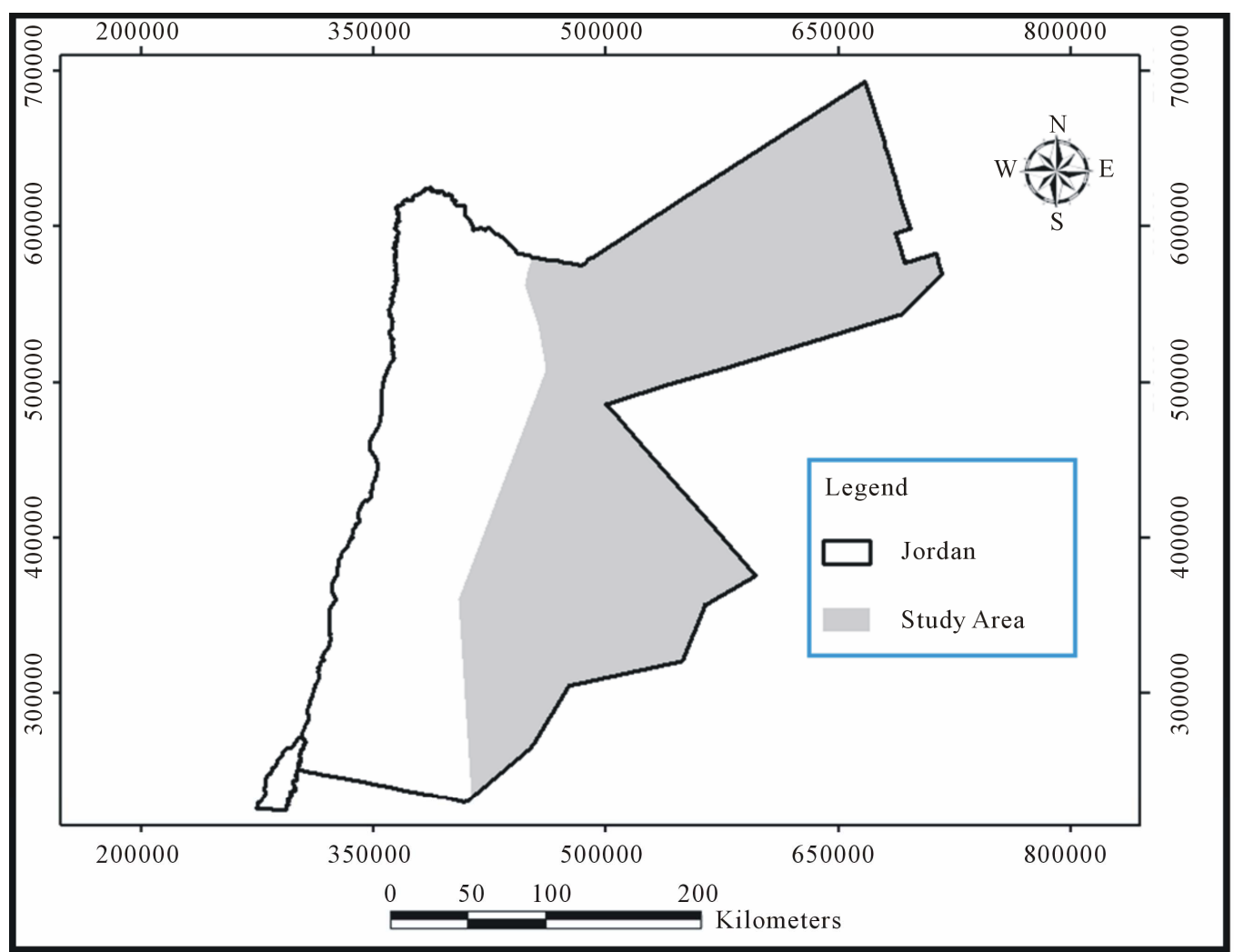

Figure 1. The study area location within Jordan.

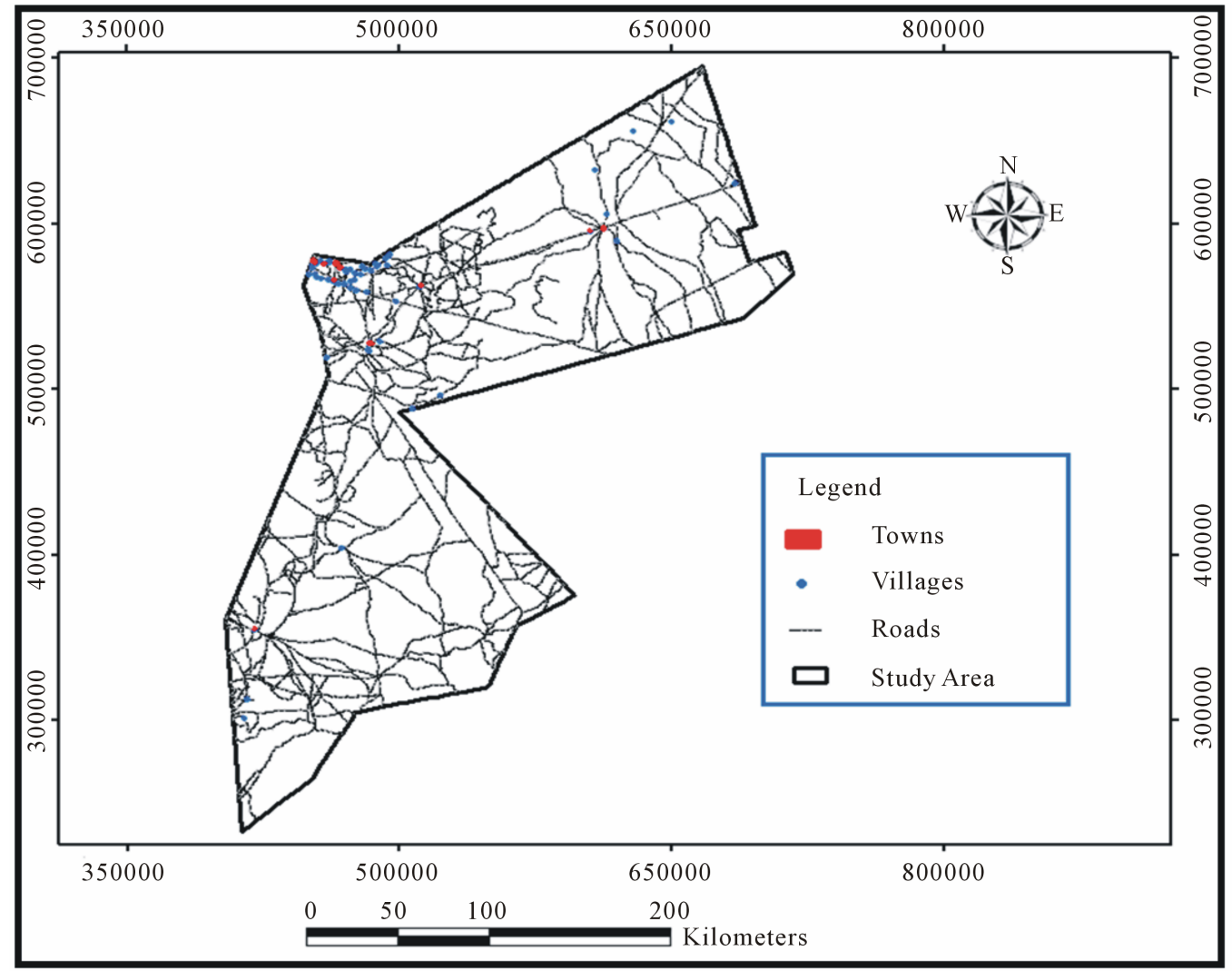

Figure 2. The population centres within the study area. 


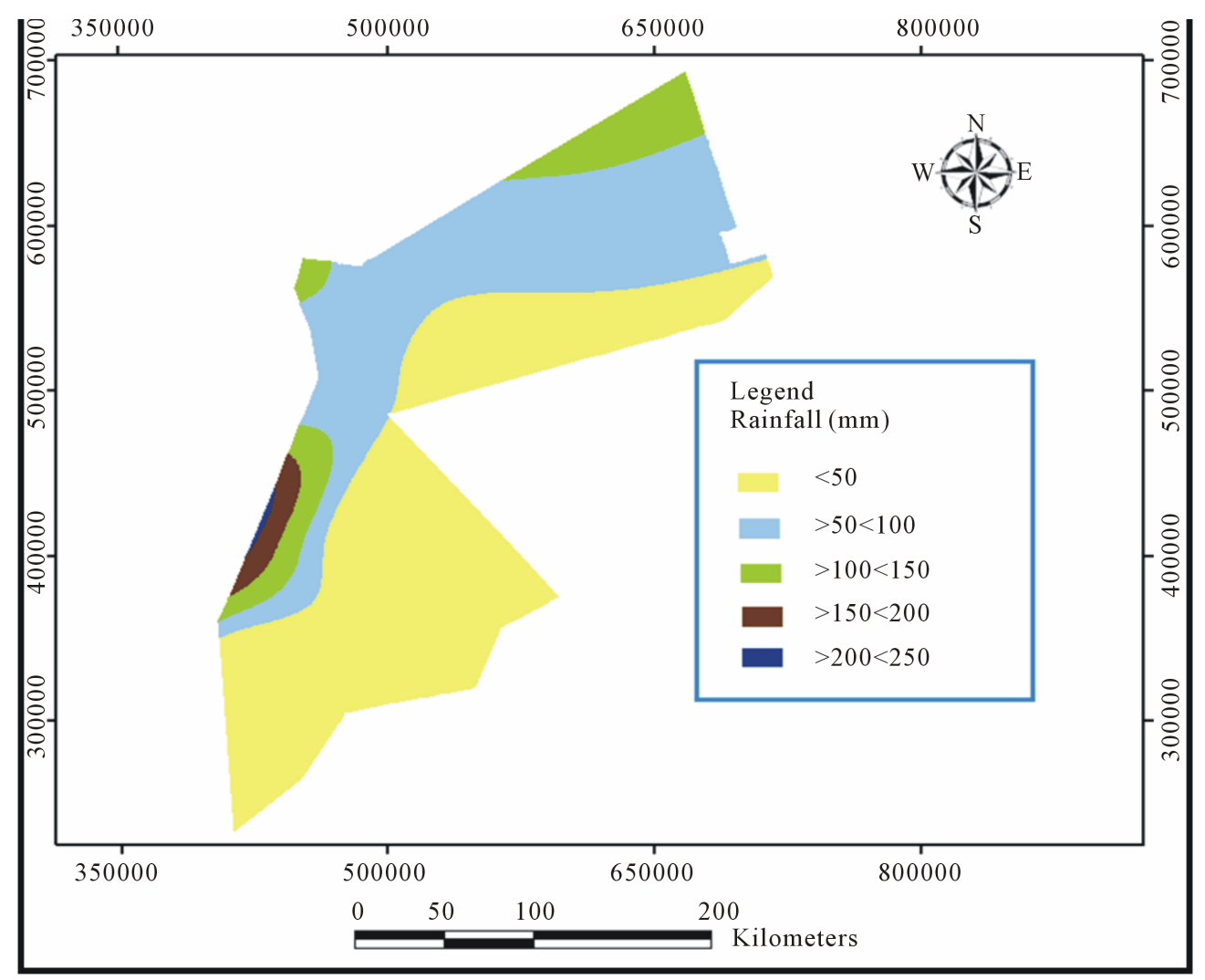

Figure 3. Rainfall isohyets for the study area.

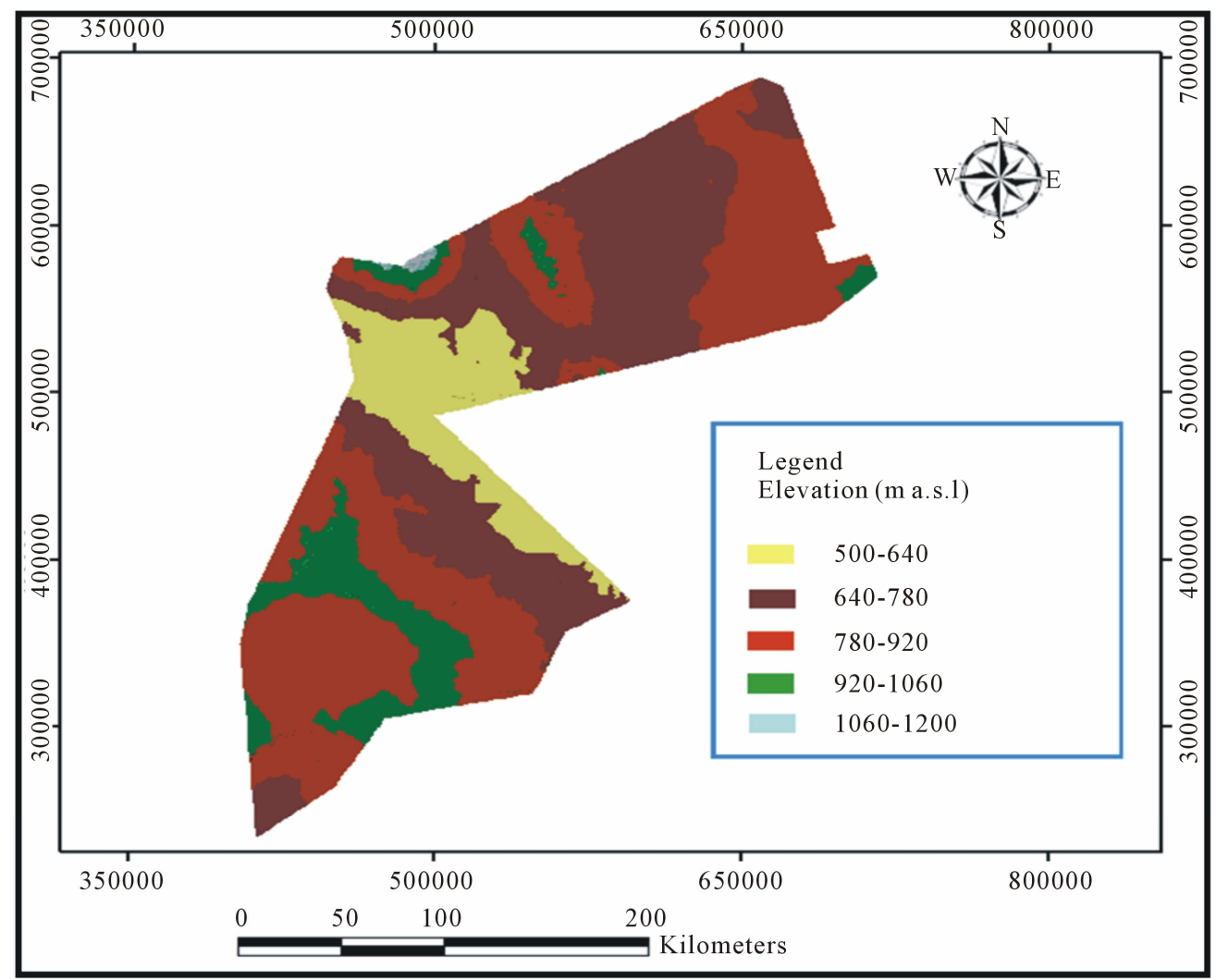

Figure 4. DEM for the study area. 


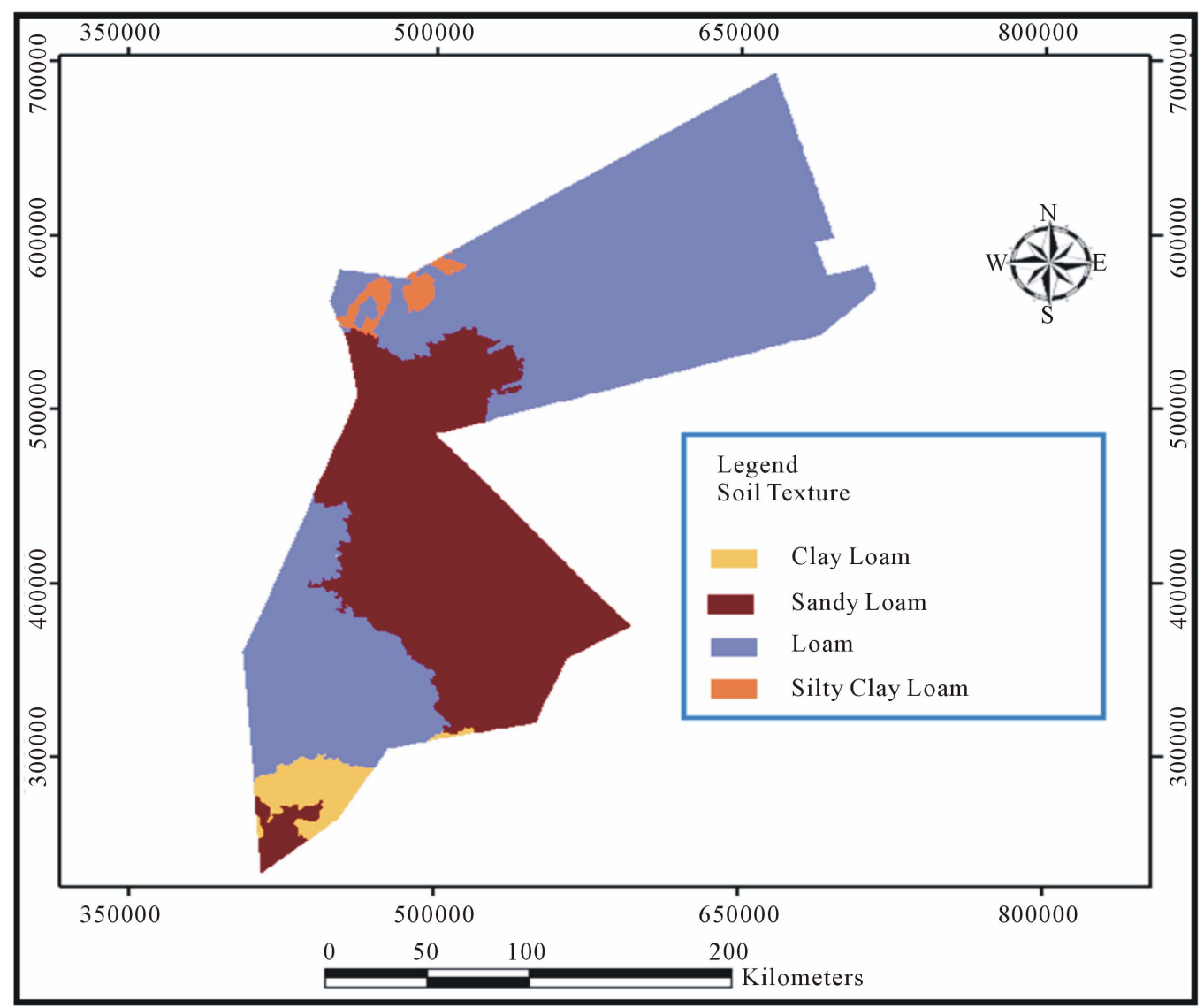

Figure 5. Soil textures within the study area.

farmers, and community leaders. The first workshop was held in the Northern Badia, where sixty persons attended the workshop. The second workshop was held in Azraq Town in the Middle Badia, where sixty persons attended the workshop. The third workshop was held in Al-Hussainyya Town in the Southern Badia, where eighty persons attended the workshop.

In these workshops, the attendants were asked to select ten sites within their area and locate them on Google Earth imageries (Figures 6-8). Also, they were asked to agree on the distances to international borders, distance to roads, distance to urban centers, distance to agriculture activities, and distance to wells (Table 1). The suggested constrains by the local communities were in agreement with the available cited literature $([6,15,16,23])$. The only difference is the distance to international border. Participants agreed that the distance between the suggested water harvesting systems should be at least $5000 \mathrm{~m}$ in unpopulated areas and at least $250 \mathrm{~m}$ in populated areas close to the international borders of Jordan.

The other type of data are secondary data which are collected from various national organizations working in the study area. These data are geo-maps for different physical and socio-economic aspects of the study area.
Table 2 lists the geo-data collected and their sources.

\subsection{Data Analysis and Results}

The socio-economic criteria for water harvesting systems, Table 1 and the physical sitting criteria, Table 3 were applied to the study area within GIS environment using ArcGIS 9.3. The methodology of analyzing the data is summarized in Figure 9.

The final map (Figure 10) shows the selected sites based on selection criteria suggested by the local communities and the available literature (118 sites). Based on the comparison between the selected sites using GIS and the suggested sites by the local communities (30 sites), it was found that there is a high degree of agreement between both outcomes. Local communities selected water harvesting sites within a reasonable proximity to the selected ones by GIS. The distances between GIS outcomes and local communities' suggestions were within $1000 \mathrm{~m}$. Most probably this difference might result from pointing on a wrong location on Google Earth imageries during the consultation workshops, or due to the satellite imageries resolution (zooming in and out). However, all sites (30) were visited in order to record their exact coordinate (i.e. the most suitable location within the selected site 


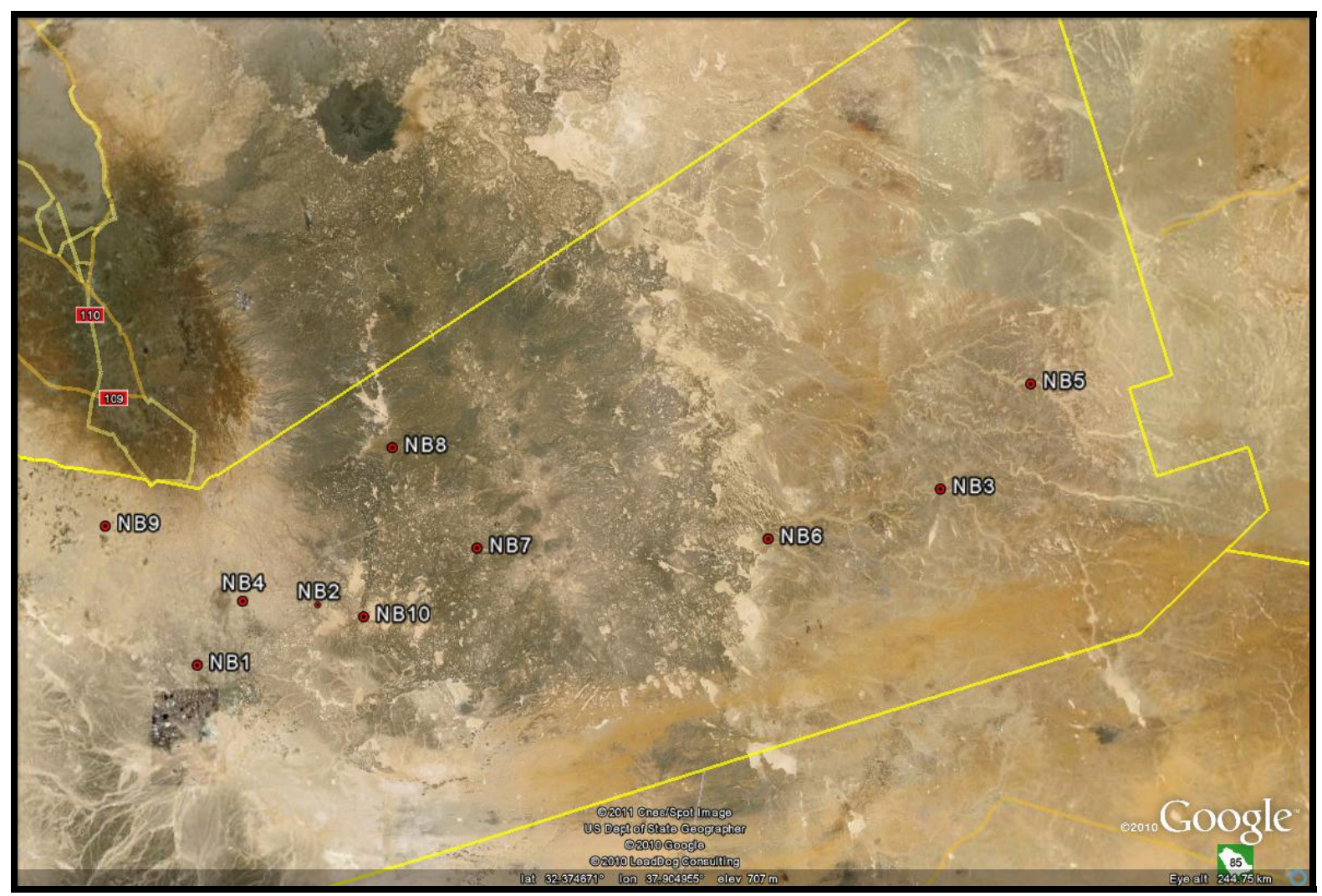

Figure 6. Suggested Water harvesting sites by local communities in North Badia.

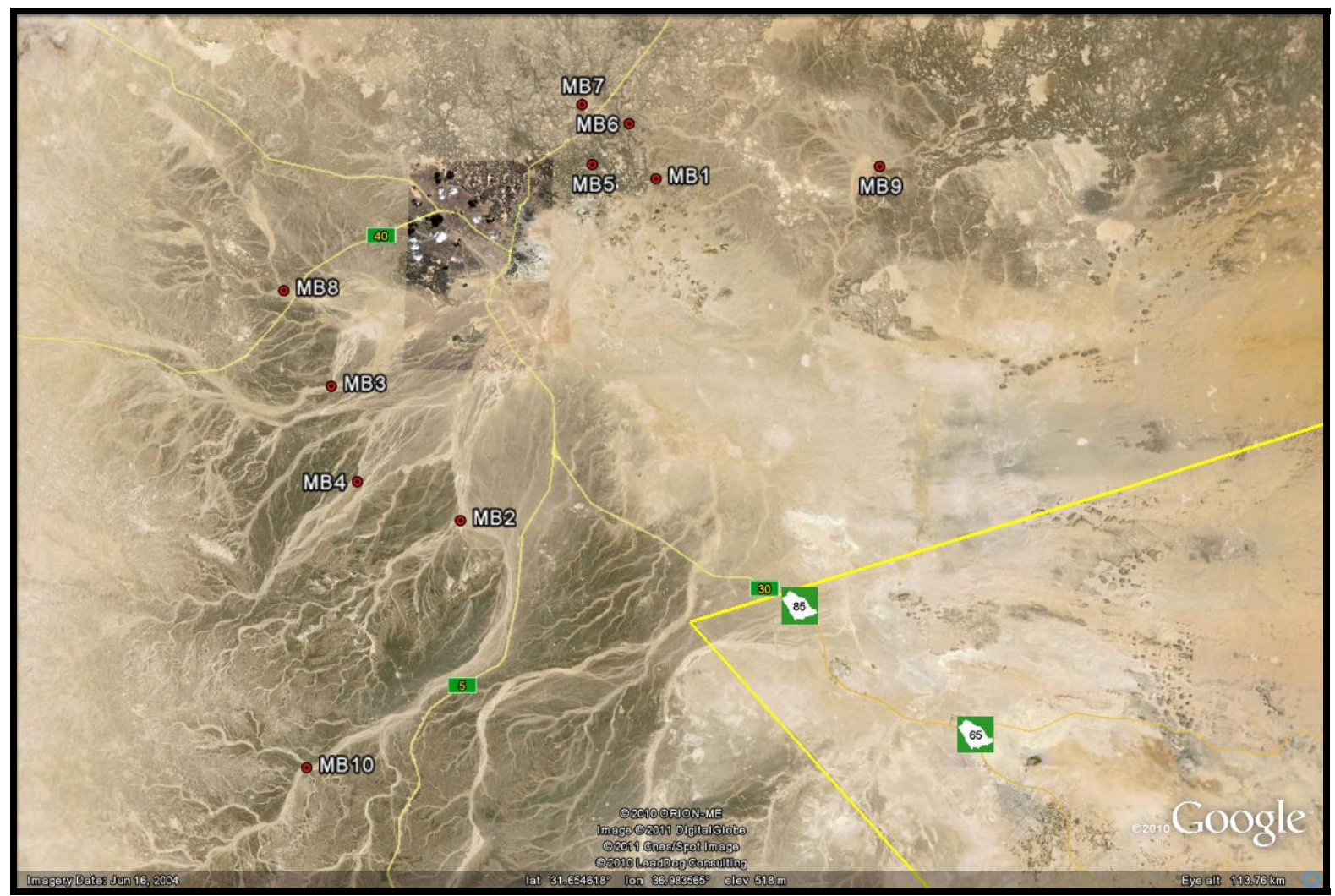

Figure 7. Suggested water harvesting sites by local communities in Middle Badia. 


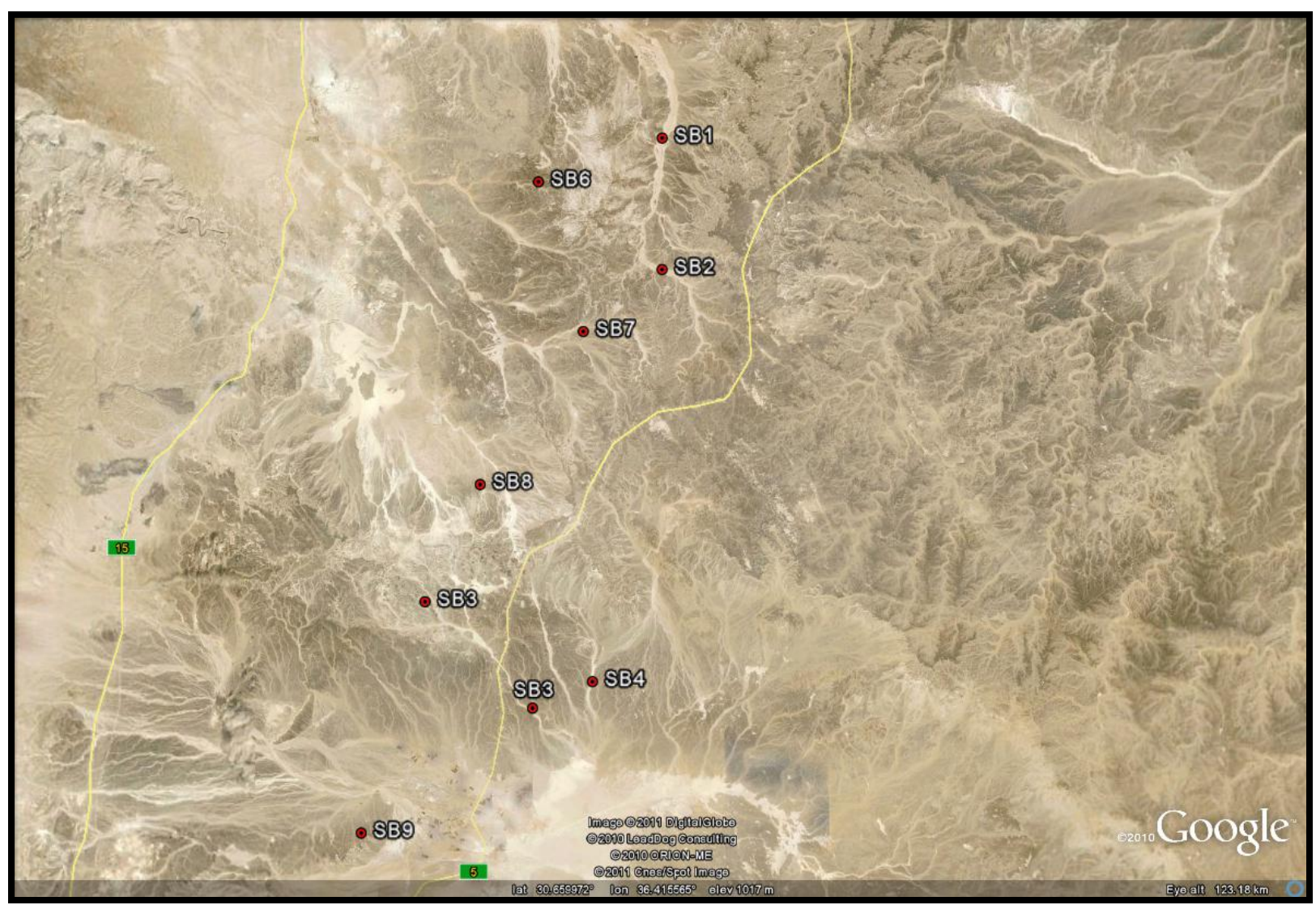

Figure 8. Suggested water harvesting sites by local communities in South Badia.

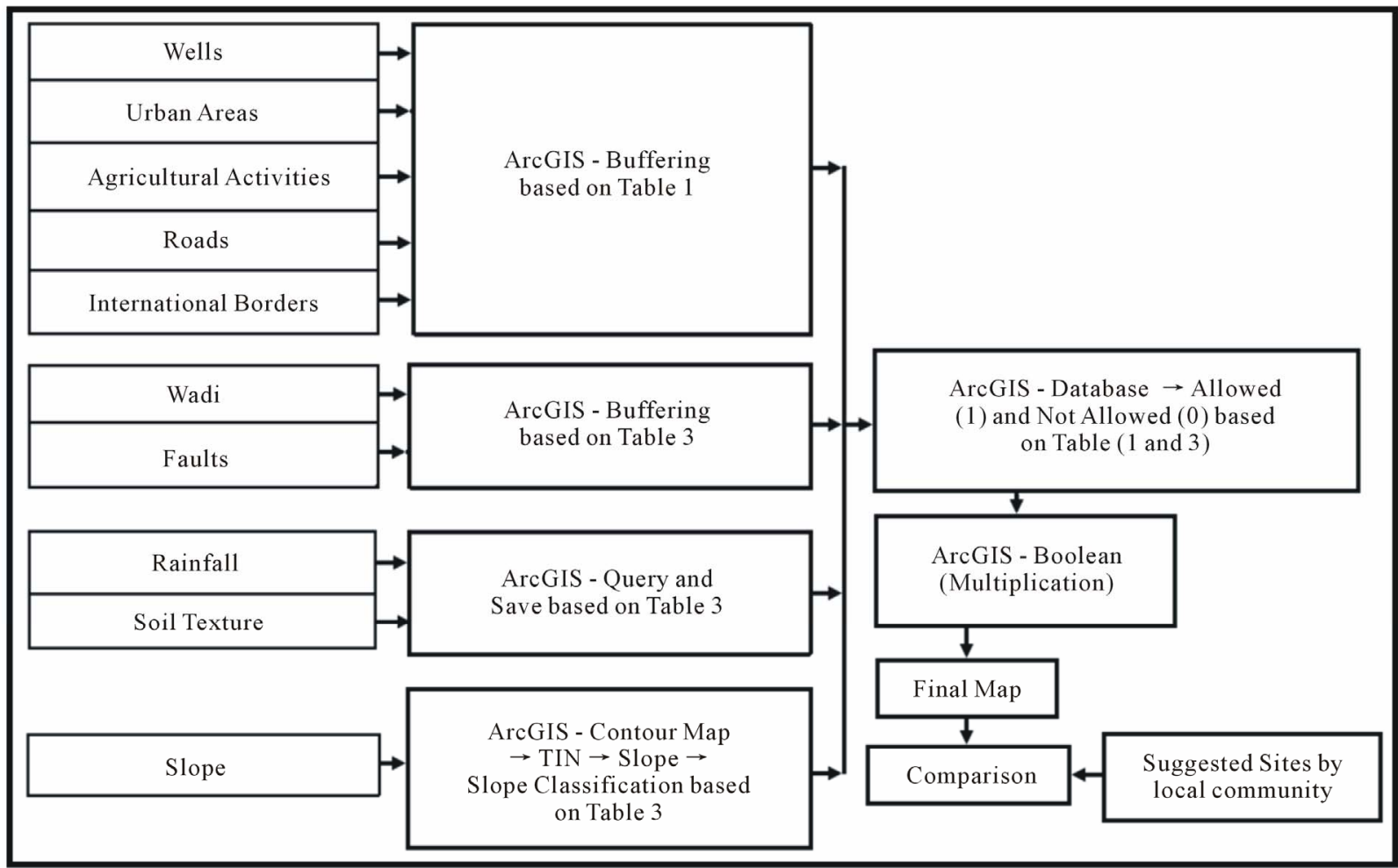

Figure 9. Data analysis methodology. 


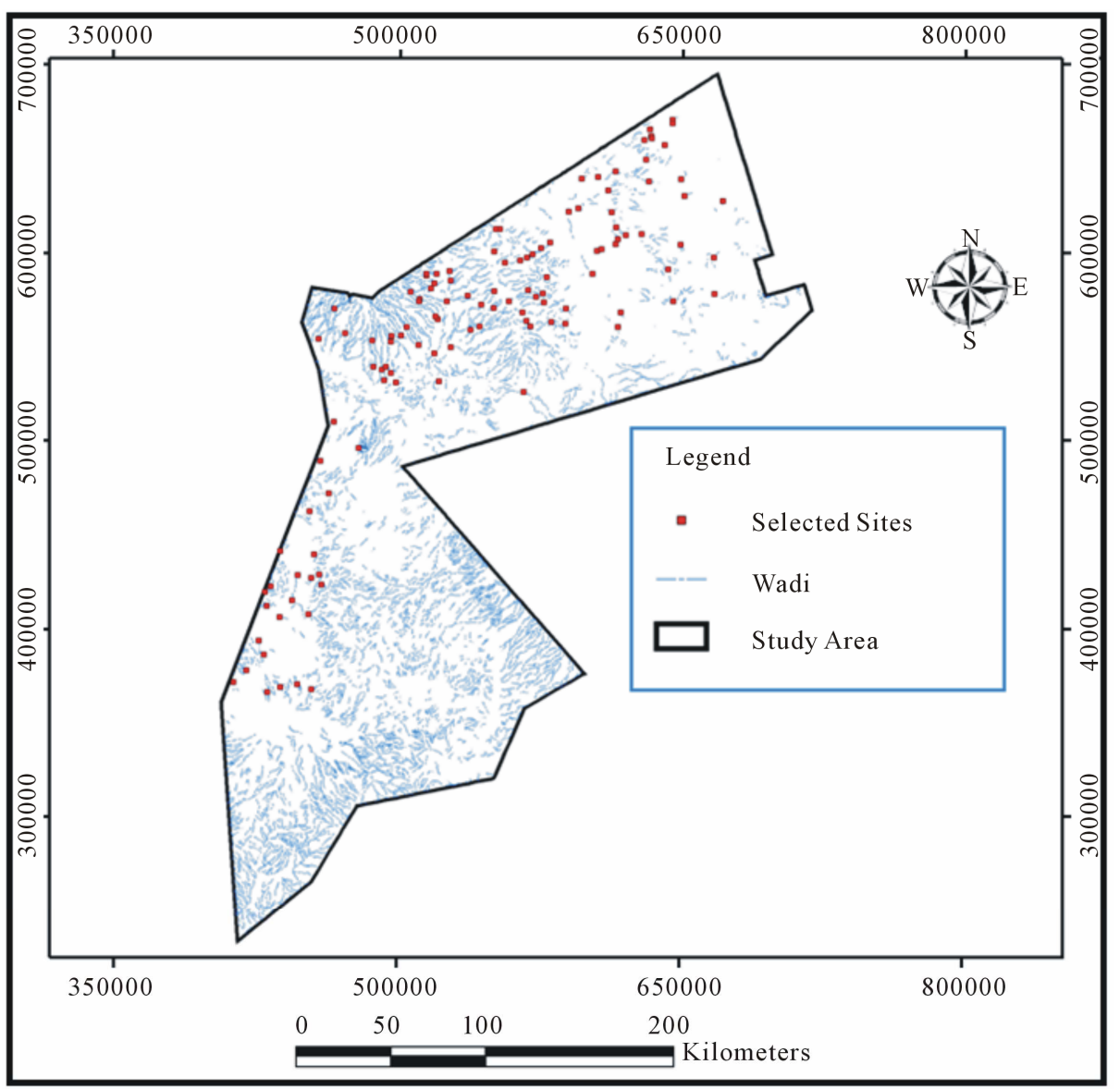

Figure 10. The selected sites using GIS.

Table 1. Suggested constraints by the local communities for selecting an optimum site for water harvesting.

\begin{tabular}{ccc}
\hline Criteria & Allowed (1) & Not Allowed (0) \\
\hline Distance to Wells (m) & More than 500 & Less than 500 \\
Distance to Urban Area (m) & More than 500 & Less than 500 \\
Distance to Agricultural Activities & More than 500 & More than 5000 \\
Distance to Roads (m) & Less than 5000 & Less than 250 (Villages Area) \\
Distance to International Borders (m) & More than 250 (Villages Area) & Less than 5000 (Uninhabited Area) \\
\hline
\end{tabular}

from hydrological point of view) as shown in Figure 11.

\section{Conclusions and Recommendations}

The integration between the local community knowledge and the Geo-informatics help decision makers in making the right decision. This research demonstrated such integration where 200 stakeholders from within the local communities in the Badia participated in providing the research team with some constrains that from their point of views are vital in choosing the suitable sites for water harvesting in their region. Also, they pointed out to certain locations within the Badia that could be utilized as a water harvesting sites based on their knowledge of the area as a livestock owners. In conclusion, water harvesting site selection is a lengthy process and needs consultation with the stakeholders, intensive fieldwork and the use of appropriate tools within GIS environment. In this research, 30 sites are found to be the most suitable sites in the Jordanian Badia for water harvesting based on GIS analysis and local communities recommendation. This does not mean that the remaining 88 sites selected by GIS are not suitable for such purpose. The 30 sites 


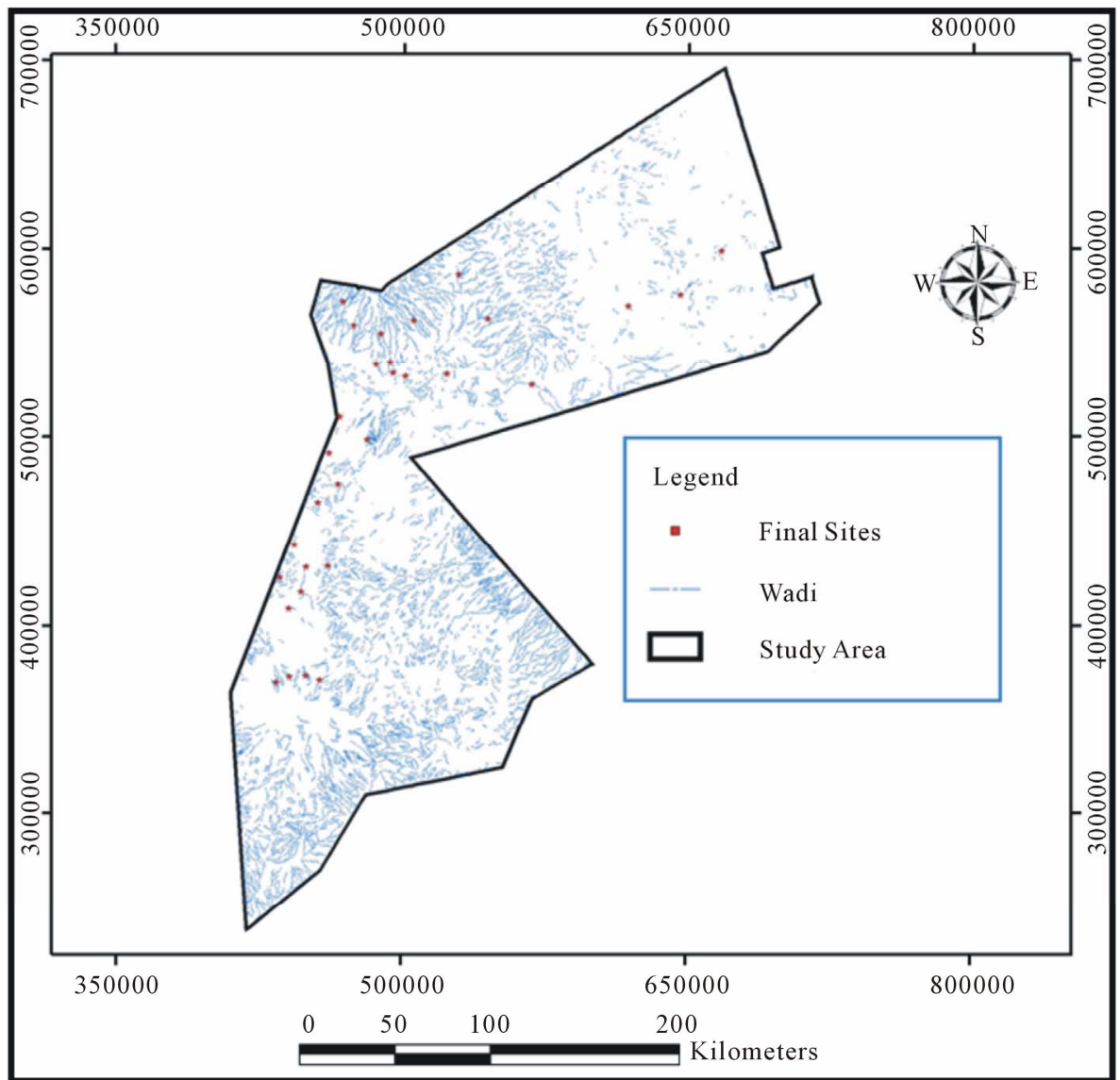

Figure 11. Final sites (GIS in combination with local communities' suggestions).

Table 2. The secondary data sets used in this research and their sources.

\begin{tabular}{cccc}
\hline Map type & Date & Scale & Source \\
\hline Town and villages & 1995 & & \\
Roads & 1995 & & \\
Borders & 1995 & & RJGC \\
Wadis & 1995 & & \\
Wadi spread & 1995 & & \\
Contours & 1995 & & WAJ \\
Wells & 1998 & & [37] \\
Rainfall & 2007 & & [37,38] \\
Soil & 2003 & $1: 500,000$ & [39] \\
Faults & 1974 & $1: 750,000$ & \\
\hline
\end{tabular}

were selected by the 200 stakeholders invited the consultation workshops. Other stakeholders might have extra sites which might be in agreement with the 88 sites.

Based on that, it is recommended that any future work
Table 3. The physical criteria (Modified from [6,15,16,27, 40,41].

\begin{tabular}{ccc}
\hline Criteria & 1 (Allowed) & 0 (Not Allowed) \\
\hline Rainfall (mm/year) & $>50$ & $\leq 50$ \\
Slope (\%) & $>5$ & $\leq 5$ \\
Distance to Wadi (m) & $\leq 500$ & $>500$ \\
Distance to Faults (m) & $>1000$ & $\leq 1000$ \\
Soil (Texture) & $\begin{array}{c}\text { Silty Loam, Loam and } \\
\text { Silty Clay Loam }\end{array}$ & Sandy Loam \\
\hline
\end{tabular}

on the use of GIS for siting any project, local communities must have their say in providing the constrains and in suggesting sites. The final say in choosing the appropriate site is the agreement between the outcome of the technology and the people requirements.

It is also, recommended that the selected sites must be investigated thoroughly to test their capability of having water harvesting schemes (dams). Such investigation could include:

1) Geophysical investigation,

2) Soil analysis, 
3) Watershed analysis.

\section{Acknowledgements}

The authors of this research would like to acknowledge that this research was funded by The Scientific Research Fund/ Jordan Ministry of Higher Education.

\section{REFERENCES}

[1] Z. S. Tarawneh, N. A. Hadadin and A. N. Bdour, "Policies to Enhance Water Sector in Jordan," American Journal of Applied Sciences, Vol. 5, No. 6, 2008, pp. 698-704.

[2] S. Nortcliff, G. Carr, R. B. Potter and K. Darmame, "Jordan's Water Resources: Challenges for the Future,” Geographical Paper, No. 185, University of Reading, Reading, 2008. http://www.reading.ac.uk/web/FILES/geog/GP185.pdf

[3] FAO (Food and Agriculture Organization of the United Nations), "Water Resources of the Near East Region: A Review," Food and Agriculture Organization of the United Nations, Rome, 1997.

[4] J. T. Winpenny, "Managing Water Scarcity for Water Security," Food and Agriculture Organization of the United Nations, Rome, 2000.

[5] R. B. Potter, K. Darmame, N. Barham and S. Nortcliff, "An Introduction to the Urban Geography of Amman, Jordan,” Reading Geographical Papers, No. 182, University of Reading, Reading, 2007.

http://www.reading.ac.uk/web/FILES/geog/GP182.pdf

[6] R. Al-Adamat, D. Abdullah and S. Ghada, "Combining GIS with Multicriteria Decision Making for Siting Water Harvesting Ponds In Northern Jordan,” Journal of Arid Environments, Vol. 74, No. 11, 2010, pp. 1471-1477. doi:10.1016/j.jaridenv.2010.07.001

[7] G. Frasier and M. Lloyd, "Handbook of Water Harvesting," US Department of Agriculture, Agricultural Research Service, Washington DC, 1983.

[8] D. Prinz, "Water Harvesting: Past and Future," In: L. S. Pereira, Ed., Sustainability of Irrigated Agriculture, Proceedings, NATO Advanced Research Workshop, Vimeiro, 21-26 March 1994, Rotterdam, 1996, pp. 135-144.

[9] R. A. AbdelKhaleq and I. A. Ahmed, "Rainwater Harvesting in Ancient Civilizations in Jordan," Water Science \& Technology: Water Supply, Vol. 7, No. 1, 2007, pp. 85-93.

[10] R. C. Srivastava, "Methodology for Optimizing of Integrated Tank Irrigation System," Journal of Water Resources Planning and Management, Vol. 122, No. 6, 1996, pp. 394-402.

[11] K. K. Gupta, J. Deelstra and K. D. Sharma, "Estimation of Water Harvesting Potential for a Semi-Arid Area Using GIS and Remote Sensing,” In: M. F. Baumgartner, G. A. Schultz and A. I. Johnson, Eds., Remote Sensing and Geographic Information Systems for Design and Operation of Water Resources Systems, International Association of Hydrological Sciences, London, 1997, pp. 53-62.
[12] G. Ravikumar, V. H. Kumaar, N. G. Anuthaman and K. Karunakaran, "A Rainwater Harvesting Information System for Chennai City, India,” IAHS-AISH Publication, No. 293, 2005, pp. 221-225.

[13] H. Wei, J-L. Li and T.-G. Liang, "Study on the Estimation of Precipitation Resources for Rainwater Harvesting Agriculture in Semi-Arid Land of China,” Agricultural Water Management, Vol. 71, No. 1, 2005, pp. 33-45. doi:10.1016/j.agwat.2004.07.002

[14] M. R. Yoklic, J. J. Riley, D. Confer, J. Robinson, B. Landcaster, A. Phillips and K. Kroesen, "Water Harvesting Potential in an Arid City: A Quantity Assessment for Tucson Arizona," USDA-CSREES National Water Conference, San Antonio, 5-9 February 2006. http://www.usawaterquality.org/conferences/2006/present ations/Yoklic.pdf

[15] G. Shatnawi, "Determine the Best Sites for Water Harvesting Projects (Dams \& Hafirs) in Northeastern Badia Using GIS Applications,” Unpublished M.Sc. Thesis, Al al-Bayt University, Mafraq, 2006.

[16] R. Al-Adamat, "GIS as a Decision Support System for Siting Water Harvesting Ponds in Jordan,” Journal of Environmental Assessment Policy and Management, Vol. 10, No. 2, 2008, pp. 189-206.

[17] A. Pandey, V. M. Chowdary, B. C. A Mal and P. P. Dabral, "Remote Sensing and GIS for Identification of Suitable Sites for Soil and Water Conservation Structures," Land Degradation \& Development, Vol. 22, No. 3, 2011, pp. 359-372.

[18] H. Weerasinghe, U. A. Schneider and A. Löw, "Water Harvest- and Storage-Location Assessment Model Using GIS and Remote Sensing," Hydrology and Earth System Sciences Discussions, Vol. 8, No. 8, 2011, pp. 3353-3381.

[19] P. Chanda, A. Singh and J. Singh, "Indigenous Knowledge Validates GIS Outcome,” Geospatial World, 2010.

[20] O. I. Chimaraoke, G. A. Ugai and J. K. Ukwayi, "Indigenous Knowledge and Communal Conflict Resolution: Evidence from Nigeria,” Indilinga: African Journal of Indigenous Knowledge Systems, Vol. 2, No. 2, 2003, pp. 114.

[21] T. Oweis, D. U. Prinz and A. Hachum, "Water Harvesting: Indigenous Knowledge for the Future of the Drier Environments," International Center for Agricultural Research in Dry Areas (ICARDA), Aleppo, 2001, p. 40.

[22] C. M. Lawas and H. A. Luning, "Farmers Knowledge and GIS,” Indigenous Knowledge and Development Monitor, Vol. 4, No. 1, 1996.

[23] R. M. Gonzalez, “KBS, GIS and Documenting Indigenous Knowledge,” Indigenous Knowledge and Development Monitor, Vol. 3, No. 1, 1995, pp. 5-7.

http://app.iss.nl/ikdm/ikdm/ikdm/4-1/articles/lawas.html

[24] C. Vorhauer and J. Hamlett, "GIS: A Tool for Siting Small Farm Ponds," Journal of Soil and Water Conservation, Vol. 51, No. 5, 1996, pp. 434-438.

[25] J. R. Eastman, "Idrisi for Windows, User's Guide, Version 2.0, Clark Labs for Cartographic Technology and Geographic Analysis,” Clark University, Worcester, 1997.

[26] S. Baban and K. Wan-Yusof, "Modelling Optimum Sites 
for Locating Reservoirs in Tropical Environments," Water Resources Management, Vol. 17, No. 1, 2003, pp. 1-17. doi:10.1023/A:1023066705226

[27] J. Malczewski, "GIS-Based Land-Use Suitability Analysis: A Critical Overview,” Progress in Planning, Vol. 62, No. 1, 2004, pp. 3-65. doi:10.1016/j.progress.2003.09.002

[28] L. Ayalew and H. Yamagishi, "The Application of GISBased Logistic Regression for Landslide Susceptibility Mapping in the Kakuda-Yahiko Mountains, Central Japan,” Geomorphology, Vol. 65, No. 1-2, 2005, pp. 15-31. doi:10.1016/j.geomorph.2004.06.010

[29] A. Yalcin, "GIS-Based Landslide Susceptibility Mapping Using Analytical Hierarchy Process and Bivariate Statistics in Ardesen (Turkey): Comparisons of Results and Confirmations,” Catena, Vol. 72, No. 1, 2008, pp. 1-12. doi:10.1016/j.catena.2007.01.003

[30] N.-B. Chang and B. J. B. Parvathinathan, "Combining GIS with Fuzzy Multicriteria for Landfill Siting in a FastGrowing Urban Region,” Journal of Environmental Management, Vol. 87, No. 1, 2008, pp. 139-153. doi:10.1016/j.jenvman.2007.01.011

[31] P. C. Longdill, T. R. Healy and K. P. Black, “An Integrated GIS Approach for Sustainable Aquaculture Management Area Site Selection,” Ocean \& Coastal Management, Vol. 51, No. 8-9, 2008, pp. 612-624. doi:10.1016/j.ocecoaman.2008.06.010

[32] I.Chenini, A. Ben Mammou and M. El May, "Groundwater Recharge Zone Mapping Using GIS-Based Multi-Criteria Analysis: A Case Study in Central Tunisia (Maknassy Basin)," Water Resources Management, Vol. 24, No. 5, 2010, pp. 921-939. doi:10.1007/s11269-009-9479-1

[33] V. Madrucci, F. Taioli and C. C. de Araújo, "Groundwater Favorability Map Using GIS Multicriteria Data Analysis on Crystalline Terrain, Saeo Paulo State, Brazil,” Journal of Hydrology, Vol. 357, No. 3-4, 2008, pp. 153-173. doi:10.1016/j.jhydrol.2008.03.026
[34] J. Ghayoumian, B. Ghermezcheshme, S. Feiznia and A. A. Noroozi, "Integrating GIS and DSS for Identification of Suitable Areas for Artificial Recharge, Case Study Meimeh Basin, Isfahan, Iran,” Environmental Geology, Vol. 47, No. 4, 2005, pp. 493-500.

[35] R. Al-Adamat, “The Use of GIS and Google Earth for Preliminary Site Selection of Groundwater Recharge in the Azraq Oasis Area-Jordan," Journal of Water Resource and Protection, Vol. 4, No. 6, 2012, pp. 395-399.

[36] J. A. Tabor and C. Hutchinson, "Using Indigenous Knowledge, Remote Sensing and GIS for Sustainable Development," Indigenous Knowledge and Development Monitor, Vol. 2, No. 1, 1994, pp. 2-6.

[37] R. Al-Adamat, et al., "Predicted Soil Organic Carbon Stocks and Changes in Jordan between 2000 and 2030 Made Using the GEFSOC Modelling System,” Journal of Agricultural Ecosystems and Environment, Vol. 122, No. 1, 2007, pp. 35-45.

[38] N. H. Batjes, Z. R. Rawajfih and R. Al-Adamat, "Soil Data Derived from SOTER for Studies of Carbon Stocks and Change in Jordan," Version. 1, GEFSOC Project Report, (2003/04), ISRIC-World Soils Information, Wageningen, 2003.

[39] F. Bender, “Geology of Jordan,” Borntraeger, Berlin, 1974, $196 \mathrm{p}$

[40] Y. D. Yang, “Application of GIS and Remote Sensing for Assessing Watershed Ponds for Aquaculture Development in Thai Nguyen, Vietnam,” 2003. http://www.gisdevelopment.net

[41] W. Critchley, K. Siegert and C. Chapman, "Water Harvesting, A Manual Guide for the Design and Construction of Water Harvesting Schemes for Plant Production," Food and Agriculture Organization of the United Nations, Rome, 1991. www.fao.org/docrep/u3160e/u3160e07.htm 